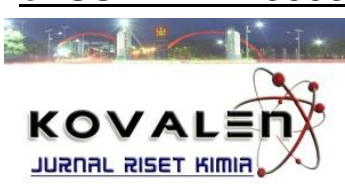

\title{
UJI AKTIVITAS ANTIBAKTERI EKSTRAK DAUN TANAMAN JOHAR (Cassia siamea Lamk.) DARI BEBERAPA TINGKAT KEPOLARAN PELARUT
}

\author{
[Antibacterial Activity Test of Johar Plant Leaf Extract (Cassia siamea Lamk.) Using \\ Several Levels of Solvent Polarity]
}

\author{
Fitriah $^{1^{*}}$, Mappiratu ${ }^{1}$, Prismawiryanti ${ }^{1}$ \\ 1 Jurusan Kimia Fakultas MIPA, Universitas Tadulako \\ Jl. Soekarno Hatta Km.9, Kampus Bumi Tadulako Tondo Palu, Telp. 0451- 422611
}

*)Coresponding author: fitriahmipa93@gmail.com (085240302412)

Diterima 25 Juli 2017, Disetujui 5 September 2017

\begin{abstract}
A research about antibacterial activity test of johar plant leaf extract (Cassia siamea Lamk.) using several levels of solvent polarity has been implemented. This study aims to determine whether the antibacterial compounds in the leaves is polar, non-polar or semi-polar, and to determine the highest inhibition level of johar leaf extract on both the gram-negative bacteria (Escherichia coli and Shigella dysenteriae) and gram-positive (Staphylococcus aureus and Micrococcus luteus). The maceration method was used in this research with 3 levels of solvent polarity namely non-polar, semi-polar and polar. The bacterial activity test was done with diffusion method. The results showed that the johar leaf contains antibacterial compounds which are polar and semi-polar. The highest inhibition level was obtained at johar leaf ethanol extract for Staphylococcus aureus, Escherichia coli, Micrococcus luteu and Shigella dysentriae of $14.9,12.9,12$, and $7.2 \mathrm{~mm}$, respectively.
\end{abstract}

Keywords: Antibacterial, Inhibition Level, Johar Leaf Extract

\begin{abstract}
ABSTRAK
Penelitian uji aktivitas antibakteri ekstrak daun tanaman johar (Cassia siamea Lamk.) dari beberapa tingkat kepolaran pelarut telah dilaksanakan. Penelitian ini bertujuan untuk mengetahui senyawa antibakteri dalam daun johar bersifat polar, non polar atau semi polar, serta daya hambat tertinggi ekstrak daun johar terhadap bakteri gram negatif (Escherichia coli dan Shigella dysenteriae) dan gram positif (Staphylococcus aureus dan Micrococcus luteus). Metode ekstraksi yang digunakan dalam penelitian yaitu metode maserasi dengan 3 tingkatan polaritas pelarut yang dimulai dari pelarut non polar ( $n$-heksan), diikuti dengan pelarut semi polar (etil asetat) dan pelarut polar (etanol). Uji daya hambat ekstrak terhadap bakteri uji dilakukan menggunakan metode difusi. Hasil yang diperoleh menunjukkan daun johar mengandung senyawa antibakteri yang bersifat polar dan semi polar. Daya hambat tertinggi diperoleh pada ekstrak etanol daun johar berturut-turut $14,9 \mathrm{~mm}$ pada bakteri Staphylococcus aureus, $12,9 \mathrm{~mm}$ pada bakteri Escherichia coli, $12 \mathrm{~mm}$ pada bakteri Micrococcus luteus dan 7,2 mm pada bakteri Shigella dysentriae.
\end{abstract}

Kata kunci : Antibakteri, Daya Hambat, Ekstrak Daun Johar 


\section{LATAR BELAKANG}

Tumbuhan memiliki banyak peranan yang penting dalam kehidupan manusia, seperti penggunaan pada pengobatan secara tradisional. Ramuan tradisional sebagian besar berasal dari tumbuhan, baik dari akar, , kayu, daun, bunga kulit batang, ataupun bijinya. Pengobatan secara tradisional memerlukan riset ilmiah untuk dapat dipertanggung jawabkan, seperti penelitian toksikologi, farmakologi, dan identifikasi serta isolasi senyawa kimia aktif yang terdapat dalam tumbuhan. Tumbuhan obat dapat digunakan sebagai antibakteri pada beberapa jenis penyakit. Indonesia yang memiliki iklim tropis terdapat beberapa jenis penyakit yang disebabkan oleh bakteri patogen dan cukup banyak diderita oleh masyarakat (Sjoekoer dkk., 2013).

Senyawa aktif pada tumbuhan yang memiliki potensi sebagai antibakteri termasuk dalam golongan senyawa metabolit sekunder. Golongan senyawa metabolit sekunder adalah alkaloid, flavonoid, saponin, tanin, steroid dan triterpenoid (Harborne, 1987). Metabolit sekunder yang telah ditemukan pada daun tanaman johar terdiri atas : saponin, antrakuinon, flavonoid dan alkaloid (Smith, 2009). Beberapa penelitian menunjukkan ekstrak metanol dan ekstrak air daun tanaman johar memiliki aktivitas anti malaria (Ajaiyeoba dkk., 2008; Morita dkk., 2007), anti diabetes (Kumar dkk., 2010), antioksidan (Kaur dkk., 2006), anti tumor dan insektisida (Kardono dkk., 2003), mempengaruhi sistem imun (Kusmardi dkk., 2006), analgesik dan anti inflamasi (Ntandou dkk., 2010). Keberadaan flavonoid dan alkaloid dalam daun johar memungkinkan ekstrak daun johar berperan sebagai antibakteri. Pernyataan tersebut didasarkan atas temuan Fatimah dkk., (2006) dalam Junanto dkk., (2008) yang menemukan ekstrak etanol daun angsana menghambat pertumbuhan bakteri Staphylococcus aureus, Streptococcuc pyogenes, dan Escherichia coli, sedangkan ekstrak kloroform dan ekstrak heksan tidak menghambat pertumbuhan bakteri Staphylococcus aureus, Streptococcuc pyogenes, Escherichia coli dan Pseudomonas aeruginosa. Murhadi dkk., (2007) melaporkan bahwa ekstrak etanol dan etil asetat daun salam dapat menghambat pertumbuhan bakteri Bacillus subtilis, Escherichia coli, Staphylococcus aureus, dan Pseudomonas aeruginosa.

Uji metabolit sekunder sebagai antibakteri selalu didahului dengan ekstraksi pelarut yang bertujuan untuk menarik metabolit sekunder yang bersifat antibakteri. Jenis kepolaran pelarut akan sangat berpengaruh terhadap hasil uji. Senyawa polar akan terlarut dalam pelarut polar, begitupun sebaliknya senyawa non polar akan terlarut dalam pelarut non polar. Sementara pelarut yang bersifat semi polar akan melarutkan senyawa aktif yang bersifat semi polar juga. 


\section{METODE PENELITIAN}

\section{Bahan dan Peralatan}

Bahan dasar yang digunakan dalam penelitian ini adalah daun tanaman johar yang diperoleh dari lingkungan kampus Universitas Tadulako. Bahan lainnya berupa bakteri patogen Staphylococcus aureus, Escherichia coli, Mikrococcus luteus dan Shigella dysenteriae, Nutrien Agar (NA), Nutrient Broth (NB), antibiotik, aquades, $n$-heksan, etil asetat, etanol, pereaksi dragendorf, serbuk magnesium, $\mathrm{HCl}$ pekat, $\mathrm{H}_{2} \mathrm{SO}_{4}$ pekat dan $\mathrm{FeCl}_{3}$, kertas saring, tissu, aluminium foil dan asam asetat anhidrat.

Peralatan yang digunakan dalam penelitian ini meliputi tabung reaksi, rak tabung reaksi, cawan petri, pembakar bunsen, blender, ayakan 60 mesh, rotary evaporator vakum, erlenmeyer, corong kaca, pipet tetes, neraca analitik, batang pengaduk, autoclave, gelas kimia, gelas ukur, alat penyaring vakum, inkubator, pipet volum, pipet mikro, jangka sorong, cork borer dan penangas air.

\section{Prosedur Penelitian}

Penelitian ini dilaksanakan dalam tiga tahapan yaitu tahap pengolahan daun johar, tahap ekstraksi daun johar dengan metode maserasi dan tahap uji aktivitas antibakteri.

\section{Tahap pengolahan daun johar}

Daun johar dicuci bersih, digunting kasar, kemudian dikeringkan dibawah sinar matahari lalu dihaluskan dengan blender dan diayak dengan ayakan 60 mesh untuk mendapatkan daun johar dalam bentuk tepung. Tepung daun johar disimpan untuk digunakan pada penelitian selanjutnya.

Tahap ekstraksi daun johar (Lisnawati, 2014)

Ekstraksi dilakukan menggunakan metode maserasi menggunakan tiga jenis pelarut. Ekstraksi pertama digunakan pelarut non polar yakni n-heksan, dengan cara menimbang tepung daun johar sebanyak $100 \mathrm{~g}$, kemudian dimasukkan ke dalam Erlenmeyer $2000 \mathrm{~mL}$, lalu ditambahkan $1000 \mathrm{~mL}$ n-heksan (perbandingan sampel dan pelarut $1: 10$ ). Campuran disimpan selama $2 \times 24$ jam, kemudian disaring dengan penyaringan vakum. Filtrat yang diperoleh dipisahkan pelarutnya dengan rotary vakum evaporator sehingga didapatkan ekstrak kental daun johar. Residu yang diperoleh dikering - anginkan dan selanjutnya dimasukkan ke dalam Erlenmeyer untuk diekstrak kembali dengan pelarut etil asetat, kemudian pelarut etanol dengan perlakuan yang sama pada ekstrak menggunakan $n$-heksan.

\section{Uji fitokimia}

Uji fitokimia dilakukan untuk mengetahui kandungan seyawa metabolit sekunder pada ekstrak dan fraksi daun johar seperti flavonoid, alkaloid, saponin, tanin dan steroid/triterpenoid dengan menggunakan pereaksi yang spesifik, meliputi : 


\section{a. Uji Alkaloid (Harborne, 1987)}

Uji alkaloid dilakukan dengan cara memasukkan $1 \mathrm{~mL}$ ekstrak ke dalam tabung reaksi lalu ditambahkan 2-3 tetes pereaksi dragendorf. Hasil positif adanya alkaloid ditunjukkan dengan terbentuknya endapan oranye/jingga.

\section{b. Uji Flavonoid (Harborne, 1987)}

Sebanyak $1 \mathrm{~mL}$ ekstrak ditambahkan $0,5 \mathrm{~g}$ serbuk magnesium dan 10 tetes $\mathrm{HCl}$ pekat (pereaksi shinoda), bila bereaksi positif akan menghasilkan larutan berwarna jingga, merah muda atau merah.

c. Uji Steroid dan Triterpenoid (Harborne, 1987)

Sebanyak $2 \mathrm{~mL}$ ekstrak ditambahkan asam asetat anhidrat sebanyak 10 tetes dan asam sulfat pekat sebanyak 2 tetes. Larutan dikocok perlahan dan diamati. Adanya steroid ditunjukan oleh warna biru atau hijau, sedangkan triterpenoid memberikan warna merah atau ungu.

\section{d. Uji Saponin (Uji Busa) (Depkes RI, 1995)}

Sebanyak 2-3 $\mathrm{mL}$ ekstrak dimasukkan ke dalam tabung reaksi, kemudian ditambahkan $10 \mathrm{~mL}$ air panas lalu didinginkan, kemudian dikocok kuatkuat selama 10 detik lalu ditambahkan 1 tetes $\mathrm{HCl} 2 \mathrm{~N}$. Uji positif ditunjukkan dengan terbentuknya buih yang stabil setinggi $1-10 \mathrm{~cm}$ selama tidak kurang dari 10 menit.

\section{e. Uji Tanin (Harborne, 1987)}

Untuk uji tanin, sebanyak $1 \mathrm{~mL}$ ekstrak ditambahkan 3 tetes larutan $\mathrm{FeCl}_{3}$ $5 \%$, bila bereaksi positif akan menghasilkan warna hijau, merah, ungu, biru atau hitam.

\section{Persiapan bahan uji antibakteri (Fitrial, 2009)}

Sebanyak 28 gram nutrient agar (NA) dilarutkan dalam $1000 \mathrm{ml}$ aquades, kemudian di sterilkan kedalam autoclave pada suhu $121^{\circ} \mathrm{C}$ dengan tekanan $1 \mathrm{~atm}$ selama 15 menit.

\section{Pembuatan suspensi bakteri uji (Fitrial, 2009)}

Satu ose bakteri diambil dari biakan agar miring dan diinokulasikan ke dalam media cair steril Nutrient Broth, kemudian diinkubasi selama 24 jam pada suhu $37^{\circ} \mathrm{C}$. Kultur bakteri siap digunakan untuk pengujian aktivitas antibakteri.

Pengujian aktivitas antibakteri dengan metode sumur difusi (Darmawati, 2009)

Media Nutrien Agar (NA) sebanyak $25 \mathrm{ml}$ dicampur dengan $25 \mu \mathrm{L}$ suspensi bakteri uji (S. Aureus, M. luteus, E. Coli dan S. dysentriae), dihomogenkan lalu dituang dalam cawan petri steril dan dibiarkan sampai memadat. Setelah itu dibuat sumur yang berdiameter $\pm 6 \mathrm{~mm}$ dengan menggunakan cork borer. Setiap cawan berisi 5 lubang atau sumur (lubang pertama untuk kontrol negatif, lubang kedua untuk kontrol positif dan 3 lubang untuk 3 jenis ekstrak), setiap sumur diisi ekstrak dengan control sebanyak $6 \mu \mathrm{L}$, kemudian diinkubasi selama 24 jam pada suhu $37^{\circ} \mathrm{C}$. Selanjutnya diamati dan diukur diameter zona hambat dengan jangka sorong. 
HASIL DAN PEMBAHASAN

\section{Metabolit Sekunder dalam Ekstrak Daun Johar}

Analisis senyawa-senyawa metabolit sekunder dalam ekstrak daun johar dilakukan dengan uji fitokimia. Hasil uji ekstrak daun johar dari tiga jenis pelarut disajikan dalam Tabel 1.

Tabel 1 Hasil analisis golongan senyawa ekstrak daun johar berdasarkan jenis pelarut

\begin{tabular}{lccc}
\hline Golongan & \multicolumn{3}{c}{ Jenis Pelarut } \\
\cline { 2 - 4 } senyawa & $\boldsymbol{n}$-heksan Etil asetat & Etanol \\
\hline Alkaloid & - & + & + \\
Flavonoid & - & - & + \\
Saponin & - & - & + \\
Tanin & - & + & + \\
Steroid & + & + & - \\
\hline
\end{tabular}

Pada Tabel 1 memperlihatkan dalam ekstrak n-heksan terdeteksi adanya senyawa steroid, tetapi tidak terdeteksi adanya alkaloid, flavonoid, saponin dan tanin. Steroid juga terdeteksi ada dalam ekstrak etil asetat, tetapi tidak terdeteksi dalam ekstrak etanol. Hal tersebut memberikan keterangan dalam daun johar terdapat dua jenis senyawa steroid, steroid yang bersifat non polar dan steroid yang bersifat semi polar. Menurut Lestiani dan Lanny (2008), tingkat kepolaran pelarut menentukan jenis dan jumlah senyawa yang dapat diekstrak dari bahan, dimana Pelarut akan mengekstrak senyawasenyawa yang mempunyai sifat kepolaran yang sama dengannya. Selain steroid, dalam ekstrak etil asetat juga terdeteksi adanya tanin dan alkaloid. Kedua senyawa ini juga terdeteksi dalam ekstrak etanol, yang berarti tanin dan alkaloid yang ada pada daun johar terdiri atas tanin dan alkaloid semi polar serta tanin dan alkaloid polar. Menurut Dewi (2013) dalam Simaremare (2014) menyatakan bahwa senyawa golongan alkaloid mengandung nitrogen sebagai bagian dari system sikliknya serta mengandung substituen yang bervariasi seperti gugus amina, amida, fenol dan metoksi sehingga alkaloid bersifat semi polar yang dapat larut dalam pelarut semi polar.

Pada Tabel 1 juga memperlihatkan golongan senyawa flavonoid dan saponin terdeteksi dalam ekstrak etanol, tetapi tidak terdeteksi dalam ekstrak etil asetat maupun ekstrak $n$-heksan, yang menunjukkan flavonoid dan saponin yang ada dalam daun tanaman johar adalah flavonoid dan saponin yang bersifat polar. Menurut Padjatmaka (1982) menyatakan bahwa pelarut etanol dapat mengekstraksi senyawa fenol, flavonoid, tanin terkondensasi, saponin dan alkaloid karena senyawa-senyawa tersebut mempunyai gugus fungsional, ikatan rangkap, atom nitrogen dan atom oksigen yang bersifat polar.

Temuan adanya saponin, alkaloid dan flavonoid dalam daun johar, juga ditemukan oleh Smith (2009) yang melakukan analisis fitokimia daun tanaman johar menggunakan pelarut etanol. Smith (2009) tidak menemukan adanya steroid karena tidak menggunakan pelarut non polar dan pelarut semi polar. Menurut Adnan (1997), pada umumnya polaritas 
senyawa organik akan meningkat dengan bertambahnya gugus fungsional dan berkurang dengan bertambahnya berat molekul.

\section{Daya Hambat Ekstrak Daun Johar}

Pengujian daya hambat ekstrak daun johar terhadap pertumbuhan bakteri $S$. aureus, M. luteus, E. coli dan S. dysentriae menggunakan tiga jenis ekstrak yaitu ekstrak $n$-heksan, ekstrak etil asetat dan ekstrak etanol. Antibiotik (Penicillin, Ofloxacin dan Chloramphenicol) sebagai kontrol positif. Pengujian ini menggunakan metode sumur difusi yang ditandai dengan terbentuknya zona bening disekeliling sumur. Pengamatan pengukuran diameter zona hambat dari masing-masing ekstrak menggunakan jangka sorong analitik. Hasil pengukuran diameter zona hambat disajikan pada Gambar 1 dan Tabel 2.

Tabel 2 Hasil pengamatan uji daya hambat ekstrak daun terhadap pertumbuhan bakteri Staphylococcus. aureus, Mikrococcus luteus, Escherichia. coli dan Shigella dysentriae.

\begin{tabular}{lccccc}
\hline \multirow{2}{*}{ Ekstrak } & \multicolumn{4}{c}{ Diameter Rata-rata Zona Hambat (mm) } \\
\cline { 3 - 6 } & S. aureus & M. luteus & E. coli & S.dysentriae \\
\hline$n$-heksan & 0 & 0 & 0 & 0 \\
Etil asetat & 12,6 & 5,1 & 9,2 & 5,8 \\
Etanol & 14,9 & 12 & 12,9 & 7,2 \\
Kontrol & Penicillin & 15,6 & - & 14,7 & - \\
Positif & Ofloxacin & - & 29,4 & - & - \\
& Chloramphenicol & - & - & - & 21,5 \\
Kontrol Negatif (0 ekstrak) & 0 & 0 & 0 & 0 \\
\hline
\end{tabular}

Pada Tabel 2 memperlihatkan ekstrak heksana tidak memberikan daya hambat terhadap semua bakteri uji. Dengan demikian steroid non polar dalam daun johar tidak bersifat antibakteri.

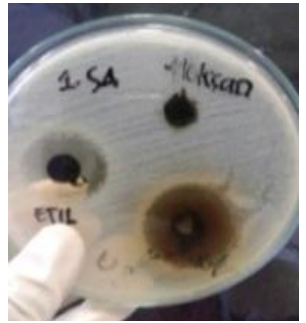

(a)

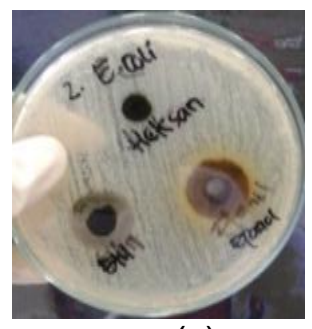

(c)

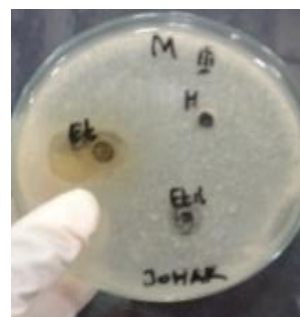

(b)

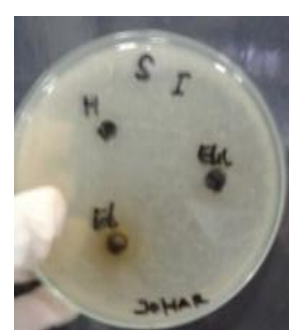

(d)
Gambar 1 Hasil uji aktivitas antibakteri ekstrak $n$-heksan, ekstrak etil asetat dan ekstrak etanol terhadap bakteri : (a) Staphylococcus aureus, (b) Micrococcus luteus, Escherichia coli dan Shigella dysentriae. 
hambat tertinggi $(12,6 \mathrm{~mm})$ ditemukan pada bakteri $S$. aureus dan zona hambat terendah $(5,1 \mathrm{~mm})$ terdapat pada bakteri uji M. luteus. Kelompok senyawa dalam ekstrak etil asetat yang berperanan sebagai antibakteri belum dapat ditemukan, perlu pengujian lanjut sebab dalam ekstrak etil asetat terdapat 3 kelompok senyawa. Jika diasumsikan hanya satu jenis senyawa yang berperanan sebagai antibakteri, maka senyawa semi polar dalam daun johar memiliki spektrum penghambatan yang luas terhadap bakteri dibandingkan dengan Penicillin, Ofloxacin dan Chloramphenicol yang hanya menghambat satu jenis bakteri dari 4 jenis bakteri yang dicobakan, kecuali Penicillin yang memberi zona hambat pada dua jenis bakteri. Menurut Renhoran (2012) umumnya kelompok bakteri gram positif lebih peka terhadap senyawa yang memiliki aktivitas antimikroba dibanding dengan gram negatif. Perbedaan sensitifitas bakteri gram positif dan bakteri gram negatif dapat disebabkan oleh perbedaan struktur dinding sel yang dimiliki oleh masingmasing bakteri.

Ekstrak etanol yang mengandung senyawa-senyawa polar (alkaloid, flavonoid saponin dan tanin) juga memberikan zona hambat terhadap semua bakteri uji. Zona hambat tertinggi (14,9 $\mathrm{mm}$ ) ditemukan pada $S$. aureus dan zona hambat terendah $(7,2 \mathrm{~mm})$ terdapat pada S. dysentriae. Menurut Davis dan Stout (1971) dalam Arista (2013), berdasarkan zona jernih atau zona bening yang terbentuk, daya hambat dikelompokkan menjadi 4 kelompok yaitu sangat kuat bila zona hambat $>20 \mathrm{~mm}$, kuat $10-20 \mathrm{~mm}$, sedang 5-10 $\mathrm{mm}$ dan lemah $<5 \mathrm{~mm}$. Berdasarkan pernyataan Davis dan Stout (1971) dalam Arista (2013), senyawa antibakteri dalam ekstrak etil asetat termasuk antibakteri zona hambat kuat terhadap $S$. aureus dan zona hambat sedang terhadap $M$. luteus, $E$. coli dan $S$. dysenteriae. Demikian pula senyawa antibakteri dalam ekstrak etanol termasuk zona hambat kuat terhadap $S$. aureus, $M$. luteus dan E. coli, tetapi zona hambat sedang terhadap S. dysentriae.

Berdasarkan hasil pengamatan diperoleh daya hambat terbesar terdapat pada ekstrak etanol yang mengandung senyawa alkaloid, flavonoid, saponin dan tanin terhadap bakteri Staphylococcus aureus. Menurut Newall dkk.,(1996) senyawa tanin dan flavonoid mempunyai aktivitas antibakteri untuk melawan Staphylococcus aureus. Senyawa tanin dapat berperan sebagai antibakteri karena dapat mengganggu sintesa peptidoglikan sehingga pembentukan dinding sel bakteri menjadi kurang sempurna. Mekanisme kerja tanin sebagai antibakteri berhubungan dengan target penyerangan tanin terhadap kerusakan polipeptida yang terdapat pada dinding sel bakteri sehingga mengganggu sintesa peptidoglikan yang menjadikan pembentukan dinding sel tidak sempurna dan mengakibatkan inaktivasi sel bakteri pada sel inang (Naim, 2004). 
Menurut Sabir (2005) dalam penelitiannya menjelaskan bahwa gugus hidroksil yang terdapat pada struktur senyawa flavonoid menyebabkan perubahan komponen organik dan transport nutrisi yang akhirnya akan mengakibatkan timbulnya efek toksik terhadap bakteri.

Hasil uji aktivitas antibakteri pelarut etanol menunjukkan dapat menghambat pertumbuhan bakteri gram negatif tetapi tidak dapat menghambat pertumbuhan bakteri gram positif. Hal ini dapat disebabkan oleh tingginya konsentrasi etanol yang digunakan (>98\%). Etanol absolut memiliki efek bakterisidal yang lebih lemah dibandingkan campuran antara alkohol dan air. Meskipun demikian, etanol pada konsentrasi $60-99 \%$ masih dapat menghambat pertumbuhan gram negatif (Ali dkk., 2001). n-Heksan tidak menunjukkan aktivitas antibakteri terhadap bakteri gram positif dan negatif. Hal ini sesuai dengan hasil penelitian Abhishek dkk., (2013) dan Ekwenchi dkk., (2014) yang menunjukkan bahwa heksan sebagai kontrol negatif tidak memiliki aktivitas antibakteri terhadap bakteri gram positif dan gram negatif. Menurut Parekh dkk., (2005) aktivitas antibakteri dipengaruhi oleh polaritas senyawa yang diekstraksi oleh masing-masing pelarut dengan kemampuan zat tersebut untuk menyebar pada media berbeda yang digunakan dalam pengujian aktivitas antibakteri.

Menurut Schlegel (1993), bahwa setiap golongan senyawa dapat memberikan efek yang berbeda dalam menghambat pertumbuhan bakteri. Perbedaan aktivitas yang terjadi tersebut disebabkan oleh metabolit sekunder yang terkandung memiliki efek sinergis yang berbeda tergantung dari sifat dan morfologi dari bakteri tersebut. Faktor lain yang menyebabkan perbedaan diameter zona hambat dari ekstrak tersebut adalah perbedaan senyawa aktif yang terdapat pada ekstrak. Hal ini sesuai dengan pendapat Prescott (2005), bahwa ukuran dari zona hambat dipengaruhi oleh beberapa hal, seperti tingkat sensitifitas dari organisme uji, kecepatan difusi dari senyawa antibakteri dan konsentrasi senyawa antibakteri.

\section{KESIMPULAN}

Berdasarkan hasil penelitian yang diperoleh dapat disimpulkan bahwa, daun johar mengandung senyawa antibakteri yang bersifat polar dan semi polar, tetapi tidak mengandung senyawa antibakteri yang bersifat non polar.

Daya hambat tertinggi ekstrak daun johar terhadap bakteri gram negatif diperoleh dari ekstrak etanol yaitu $12,9 \mathrm{~mm}$ pada bakteri Escherichia coli, sedangkan pada bakteri gram positif yaitu $14,9 \mathrm{~mm}$ pada bakteri Staphylococcus aureus.

\section{UCAPAN TERIMAKASIH}

Secara khusus peneliti menyampaikan ucapan terima kasih kepada Laboran Jurusan Kimia dan Himpunan Mahasiswa Kimia (HIMAKIM) FMIPA UNTAD. 


\section{DAFTAR PUSTAKA}

Abhishek, S., Ujwala, P., Shivani, K., dan Meeta, B. 2013. Antibacterial activity of Tecomella undulata leaves crude extracts. International Journal of Biological Sciences. 2 (6): 60-62.

Adnan, M. 1997. Teknik Kromatografi untuk Analisis Bahan Makanan. Edisi Pertama. Cetakan Pertama. Yogyakarta: Penerbit Andi.

Ajaiyeoba, E.O ; J.S. Ashidi; L.C Okpako; P.J. Houghton dan C.W.Wright. 2008. Antiplasmodial compounds from Cassia siamea stem bark extract. Phytoteraphy Research 22 (2): $254-255$.

Ali, Y., Dolan, M. J., Fendler, E. J., dan Larson, E. L. 2001. Alcohols. Dalam Block, S. S. (ed.). 2001. Disinfection, Sterilization, and Preservation. Edisi ke- 5. Lippincott Williams and Wilkins, Philadelphia. Halaman 231 dan 234.

Arista, Y. N. 2013. Formulasi dan Uji Aktivitas Gel Antijerawat Ekstrak Umbi Bakung (Crinum Asiaticum L.) terhadap Bakteri Staphylococcus aureus secara In Vitro. (http://ejournal.unstrat.ac. id/index. php/pharmacon/article/ view/1552). Diakses 1 November 2016.

Darmawati, S. 2009. Keanekaragaman Genetik Salmonella typhi. Jurnal Kesehatan, 2 (1): 28-32

Depkes RI. 1995. Farmakope Indonesia. Jakarta: Departemen Kesehatan Republik Indonesia.

Ekwenchi, M. M., Oluigbo, J., Akpuaka, A. 2014. Antibacterial activity of $n$ hexane extract of Ocimum gratissimum leaves. IOSR Journal of Applied Chemistry 7(5): 6 -10.
Fitrial, Y. 2009. Analisis Potensi Biji dan Umbi Teratai (Nymhaea pubescens Willd) untuk Pangan Fungsional Prebiotik dan Antibakteri Escherichia coli. Enteropatogenik K1.1. (Tesis). Bogor: Pasca Sarjana Institut Pertanian Bogor.

Harborne, J.B. 1987. Phytochemical methods. Diterjemahkan oleh Kosasih Padmawinata dan Iwang Sudiro. Bandung: Penerbit ITB.

Junanto, T., Sutarno., Supriyadi. 2008. Aktivitas Antimikroba Ekstrak Angsana (Pterocarpus indicus) terhadap Bacillus subtilis dan Klebsiella pneumonia. Jurnal Bioteknologi. 5 (2): 63 - 69.

Kardono, L.B.S; N. Artanti, I.D Dewi Yanti, T. Basuki. 2003. Selected Indonesian Medicinal Plants. Monographs and Descriptions Vol. 1. Jakarta: Gramedia Widiasarana Indonesia.

Kaur, G., M.S. Alam, Z. Jabbar, K. Javed dan M. Athar. 2006. Evaluation of antioxidant activity of Cassia siamea flowers. Journal of Ethnopharmacology 108 (3): 340 348.

Kumar, S., V. Kumar dan O. Prakash. 2010. Antidiabetic and anti-lipemic effects of Cassia siamea leaves extract in streptozotocin induces diabetic rats. Asian Pasific Journal of Tropical Medicine, $871-873$.

Kusmardi, S. Kumala, D. Wulandari. 2006. Pengaruh pemberian ekstrak etanol daun johar (Cassia siamea Lamk) terhadap peningkatan aktivitas dan kapasitas fagositosis sel makrofag. Makara Kesehatan. 10 (2): 89 - 93

Lestiani, Lanny. 2008. Vitamin Larut Air. Universitas Indonesia. Jakarta. 
Lisnawati. 2014. Aktivitas Antioksidan Ekstrak Daun Kelor (Moringa oleifera L.) Dari Berbagai Tingkat Kepolaran Pelarut. (Skripsi). FMIPA Kimia. Universitas Tadulako. Palu.

Morita, H.; S. Oshimi, Y. Hirasawa, K. Koyama, T. Honda, W. Ekasari, G. Indrayanto, N.C. Zaini. 2007. Cassiarins $A$ end $B$, novel antiplasmodial alkaloid from Cassia siamea. Organic Letters. 9 (18): 3691 - 3693.

Murhadi, Suharyono AS., Susilawati. 2007. Aktivitas Antibakteri Ekstrak Daun Salam (Syzygium polyanta) dan Daun Pandan (Pandanus amaryllifolius). Jurnal Teknologi dan Industri Pangan. 18 (1): 17 24.

Naim, R. 2004. Senyawa Antimikroba Dari Tumbuhan. (http://www2.kompas. com/kompas-cetak/0409/15/sorotan /1265265.htm). Diakses Tanggal 6 Desember 2016.

Newall, CA. Anderson LA., Phillipson,JD. 1996. Herbal Medicines A Guide for Health-care Prefessionals. London: The Pharmaceutical Press.

Ntandou, G.F.N., J.T. Banzouzi, B. Mbatchi, R.D.G. Elion-Itou, A W. Eou-Ossibi, S. Ramos, F. Benoit Vical, A.A. Abena, J.M. Oumba. 2010. Analgesic and antiinflammatory effects of Cassia siamea Lamk. Stem bark extracts. Journal of Ethnopharmacology. 127 (1): $108-111$.

Padjatmaka. 1982. Kimia Organik I. Erlangga. Jakarta. Terjemahan: Organic Chemistry. Fessenden, R, J., and Fessenden, J, S., Wardsworth. Inc., Belmont. California.

Parekh, J., Jadeja, D., Chanda, S. 2005. Efficacy of Aqueous and Mathanol
Extracts of Some Medicinal Plants for Potential Antibacterial Activity. Turk J Biol. 29: 203 - 210.

Prescott, LM. 2005. Microbiology. New York: Mc.Grow-Hill.

Renhoran, W. 2012. Aktivitas Antioksidan dan Mikrobiologi Ekstrak Sargassum polycistum. (Skripsi). Bogor: Departemen Teknologi Hasil Perairan Fakultas Perikanan dan IImu Kelautan IPB.

Sabir A. 2005. Aktivitas antibakteri flavonoid propolis Trigona $s p$ terhadap bakteri Streptococcus mutans (in vitro). Maj. Ked. Gigi. 38: 135 - 141.

Schlegel, G. Hans. 1993. General Microbiology. Seventh Edition. England: Cambridge University Press.

Simaremare, E. S., 2014. Skrining Fitokimia Ekstrak Etanol Daun Gatal (Laporteae decumana (Roxb) Wedd). Pharmachy. 11 (1): 98 107.

Sjoekoer, D.M., Roetiningsih, Sinarto, S. 2003. Bakteriologi Medik. Jakarta: Banyumedika.

Smith, Y.R.A. 2009. Determination of chemical composition of Sennasiamea (Cassia leaves). Pakistan Journal of Nutrition 8 (2); 119 -121. 